\title{
Study on genetic variability and heritability in rice landraces (Oryza sativa. L.) under sodicity
}

\author{
S. Manju ${ }^{1}$, T. Thirumurugan ${ }^{1 *}$, A. Subramanian ${ }^{1}$, S. Nithila ${ }^{1}$, \\ T. Sherene Jenita Rajammal ${ }^{2}$ and P. Jeyaprakash ${ }^{1}$
}

\author{
${ }^{1}$ Anbil Dharmalingam Agricultural College \& Research Institute, Tamil Nadu Agricultural \\ University, Trichy-620 027, India \\ ${ }^{2}$ National Pulses Research Centre, Tamil Nadu Agricultural University, \\ Vamban-622 303, India \\ *Corresponding author
}

\section{A B S T R A C T}

\begin{tabular}{|l|}
\hline Ke y w or d s \\
Rice landraces, \\
Genetic variability, \\
Sodicity
\end{tabular}

\section{Introduction}

Rice (Oryza sativa L.) is the major source of food for one-third of the global population and $70 \%$ of Indian population. Salt affected areas in India were found to be $6.7 \mathrm{mha}$. Out of which 2.9 mha areas were saline and 3.7 mha area were sodic (Mandal et al., 2011). In India, rice is grown in 43.79 million ha area with production and productivity of 116.42 million tonnes and 2.7 tonnes/ha. Tamil Nadu accounts for 6.45 million tonnes of production and 3.7 tonnes/ha and productivity of rice in an area of 1.72 mha (Agricultural statistics, 2019)

Salt stress adversely affects crop growth by reducing photosynthetic capacity of plants. High level of sodium in soil causes osmotic stress on cell water relations and increase the toxicity of sodium in the cytosol leading to damage of cell metabolism and photosynthesis (Gupta et al., 2020).

$\mathrm{Na}^{+}$and $\mathrm{K}^{+}$show similar ionic as well as physical and chemical properties. $\mathrm{K}^{+}$plays 
major role in many physiological process and cell metabolism for normal growth and development. Under salt stress conditions, $\mathrm{Na}^{+}$concentration exceeds the optimal level, reducing $\mathrm{K}^{+}$uptake in roots. This causes lesser retention of $\mathrm{K}^{+}$in different plant parts. $\mathrm{Na}^{+}$enters $\mathrm{K}^{+}$pathway and alters ion ratio in the cytosol leading to toxicity. Salt tolerant plants maintain low cytosolic $\mathrm{Na}^{+} / \mathrm{K}^{+}$ratio through some strategies viz., extrusion of excess $\mathrm{Na}^{+}$through roots and compartmentalization in different parts, which in turn decreases $\mathrm{Na}^{+}$concentration in cytosol. This osmotic adjustment aids in overcoming adverse salt effects, thus producing considerable yield (Chakraborty et al., 2018).

Due to continuous cultivation of high yielding varieties there is loss of variability in local cultivars. Landraces have high genetic variability and are highly tolerant to abiotic and biotic stresses owing to reasonable yield. Hence, landraces should be conserved and utilized as parents in breeding programme to prevent loss of genetic variability.

The genetic variability parameters such as Phenotypic Coefficient of Variation (PCV), Genotypic Coefficient of variation (GCV), Heritability and Genetic Advance as percent Mean (GAM) are useful in identifying the extent of variation present in the population. The present investigation was undertaken to assess the variability parameters contributing to yield and to identify salt tolerant rice landraces.

\section{Materials and Methods}

The present study was carried out at Anbil Dharmalingam Agricultural College and Research Institute, Tamil Nadu Agricultural University, Trichy, Tamil Nadu during October 2019 to February 2020 (late samba 2019) under sodic soil condition with EC 1.3 $\mathrm{dSm}^{-1}$; $\mathrm{pH} 8.85$ and ESP 43.2 respectively.
The experimental material composed of 71 genotypes including 64 landraces and seven cultivars (Table 1). The experimental field was laid out using randomized block design with three replications. Seeds were sown on raised nursery beds and transplanted in the experimental field by adapting spacing of $20 \times 20 \mathrm{~cm}$. Recommended agricultural practices were practiced for normal establishment of crop.

Observations were recorded for ten traits including eight morphological and two physiological traits viz., days to $50 \%$ flowering, plant height, number of productive tillers per plant, panicle length, number of grains per panicle, spikelet fertility percentage, chlorophyll content, $\mathrm{Na}^{+} / \mathrm{K}^{+}$ Ratio, 1000 grain weight and grain yield per plant. $\mathrm{Na}^{+} / \mathrm{K}^{+}$Ratio for the rice landraces were estimated by flame photometry method and chlorophyll content was recorded using SPAD (Soil Plant Analysis Development) meter. Analysis of variance and estimates of coefficient of variation (phenotypic and genotypic) were estimated as per the methodology proposed by Panse and Sukhatme (1967) and Burton (1952). Heritability in broad sense (Lush, 1940) and genetic advance as percent of mean (Johnson et al., 1955) were also estimated for the characters studied. The range of heritability was classified as low (10-30\%), medium (30$60 \%)$ and high $(>60 \%)$ as suggested by Johnson et al., (1955). The genetic advance for the traits were classified as high $(>20 \%)$, moderate $(10-20 \%)$ or low $(<10 \%)$ as given by Johnson et al., (1955). The statistical analysis was carried out using TNAUSTAT software.

\section{Results and Discussion}

Genetic variability is much essential for the survival of species. The extent of variation present in the genotypes should be exploited 
for choosing the breeding programme to be adapted and for the improvement of cultivars. Analysis of variance showed that the mean sum of squares for genotypes were highly significant for all the characters studied (Table 1). It indicates that presence of high variability for the traits in rice landraces used in the study.

Table 3. represents mean and range for different traits of rice genotypes Pokkali, AC39389 (Chettivirippu) and AC39394 (Chettivirippu) recorded minimum number of days to $50 \%$ flowering (72.0) followed by Thattan samba (75.0), Kuthir (76.0) and Poongar (76.7) and the maximum number of days to $50 \%$ flowering was registered by Poovan samba (108.3). The trait plant height showed wide range of variation from 91.67 $\mathrm{cm}$ to $201.07 \mathrm{~cm}$ with a mean value of 142.25 $\mathrm{cm}$. Landrace Kaatuyaanam $(91.67 \mathrm{~cm})$ was found to be the tallest genotype and TKM 13 $(201.07 \mathrm{~cm})$ was the shortest. The landrace Navaraan (16.47) produced maximum number of tillers and Malayalathan samba (6.13) produced least number of tillers. The mean value of the above trait was 10.58 . The shortest panicle length was observed in the landrace Jeeraga samba $(18.41 \mathrm{~cm})$ while longest panicle length was observed in Kichali samba $(28.66 \mathrm{~cm})$. This trait registered mean value of $23.36 \mathrm{~cm}$. The range of number of grains per panicle varied from 63.78 to 244.67 with a mean value of 136.88 . Karunguruvai produced minimum (63.78) and Rajamannar (244.67) produced maximum number of grains per panicle. The trait spikelet fertility percentage ranged from $73.66 \%$ to $98.06 \%$ with a mean value of $90.06 \%$. Milagu samba $(98.06 \%)$ expressed highest and Pisini (73.66\%) expressed lowest spikelet fertility percentage. The mean value observed for chlorophyll content was 32.78. Sandikar recorded (24.60) low and AC39389 (41.79) recorded high chlorophyll content. $\mathrm{Na}^{+} / \mathrm{K}^{+}$ratio varied from $0.03 \mathrm{ppm}$ (Poovan samba) to $0.94 \mathrm{ppm}$ (Mattakuruvai) with mean $\mathrm{Na}^{+} / \mathrm{K}^{+}$ratio of $0.35 \mathrm{ppm}$. Range for 1000 grain weight varied from $13.80 \mathrm{~g}$ to $32.58 \mathrm{~g}$ with an average of $22.98 \mathrm{~g}$. Malayalathan samba (32.58 g) was found to be the landrace with highest 1000 grain weight and TKM 13 found to be the lowest with $13.80 \mathrm{~g}$. TRY 3 was identified as the highest yielding genotype with grain yield per plant of $43.36 \mathrm{~g}$ followed by the landraces Poovan samba (43.29 g), Rajamannar (41.81), Katta samba (41.68 g) and Sorna kuruvai (40.60 g). Mattakuruvai recorded lowest grain yield per plant of $9.74 \mathrm{~g}$ followed by Kichali samba (11.90 g), Kuliyadichan $(13.02$ g), Karunguruvai (13.86 g) and Shenmolgi (14.75 g).

Estimates of genotypic coefficient of variation (GCV), phenotypic coefficient of variation (PCV), broad sense $\left(h^{2}\right)$ heritability and genetic advance as per cent of mean (GAM) were given in Table 3. PCV and GCV along with heritability and genetic advance as percent mean for the traits favours in determining the breeding programme to be followed for the purpose of crop improvement.

High PCV and GCV was expressed by the traits such as $\mathrm{Na}^{+} / \mathrm{K}^{+}$ratio $(59.33 \%, 57.66 \%)$, grain yield per plant $(31.11 \%, 30.54 \%)$, number of grains per panicle $(28.59 \%$, $28.54 \%$ ), number of productive tillers per plant $(23.75 \%, 22.99 \%)$ and 1000 grain weight $(23.20 \%, 23.07 \%)$. Similar findings were reported by Dhakal et al., (2020) for number of productive tillers per plant, Kumar et al., (2020) for number of grains per panicle and Devi et al., (2020) for 1000 grain weight and grain yield per plant and Keerthana et al., (2019) for $\mathrm{Na}^{+} / \mathrm{K}^{+}$ratio.

The traits plant height $(18.78 \%, 18.68 \%)$ and days to $50 \%$ flowering $(10.73 \%, 10.65 \%)$ showed moderate PCV and GCV. These 
findings were in agreement with Akter et al., (2018) for plant height and Behera et al., (2018) for days to $50 \%$ flowering.

The traits, panicle length $(11.05 \%, 9.76 \%)$ and chlorophyll content (10.53\%, 9.62\%) exhibited moderate PCV and low GCV.
Spikelet fertility percentage $(6.61 \%, 6.30 \%)$ showed low PCV and GCV. The results were in accordance with the findings of Jadhav et al., (2020) for panicle length and spikelet fertility percentage and Shrivastav et al., (2020) for chlorophyll content.

Table.1 List of rice landraces

\begin{tabular}{|c|c|c|c|}
\hline S. No & Genotypes & S. No & Genotypes \\
\hline 1. & Singinikar & 37. & Poombalai \\
\hline 2. & Vaadan samba & 38. & Kichali samba \\
\hline 3. & Kaatu samba & 39. & Kulivedichan \\
\hline 4. & Katarni & 40. & Murugankar \\
\hline 5. & Navaraan & 41. & Katta samba \\
\hline 6. & Vaal sigappu & 42. & Shenmolgi \\
\hline 7. & Jeeraga samba & 43. & Vellaichithirai kar \\
\hline 8. & Swarna kichadi & 44. & Malayalathan samba \\
\hline 9. & Sandikar & 45. & Kodai \\
\hline 10. & Milagu samba & 46. & Sorna kuruvai \\
\hline 11. & Rajamudi & 47. & Kattikar \\
\hline 12. & Salem samba & 48. & Ponmani samba \\
\hline 13. & Karuthakar & 49. & Seevana samba \\
\hline 14. & Karunguruvai & 50. & Matta kuruvai \\
\hline 15. & Rasakedam & 51. & Sirumani \\
\hline 16. & Pisini & 52. & Palkachaka \\
\hline 17. & Rajamannar & 53. & Mattaikar \\
\hline 18. & Kottara samba & 54. & Vadivel \\
\hline 19. & Rathasali & 55. & Panamara samba \\
\hline 20. & Iluppaipoo samba & 56. & Kalarkar \\
\hline 21. & Poongar & 57. & Thillainayagam \\
\hline 22. & Kalanamak & 58. & Norungan \\
\hline 23. & Kuliyadichan & 59. & Thattan samba \\
\hline 24. & Kothamalli samba & 60. & Senkar \\
\hline 25. & Koombalai & 61. & Pokkali \\
\hline 26. & Kaatu ponni & 62. & AC 39389 (Chettivirippu) \\
\hline 27. & Thooyamalli & 63. & AC 39394 (Chettivirippu) \\
\hline 28. & Cochin samba & 64. & Kuthir \\
\hline 29. & Kavuni sigappu & 65. & Bhavani \\
\hline 30. & Kaatuyaanam & 66. & TRY 1 \\
\hline 31. & Garudan samba & 67. & TRY 2 \\
\hline 32. & Poovan samba & 68. & TRY 3 \\
\hline 33. & Kallimadayan & 69. & ADT 43 \\
\hline 34. & Vasaramundan & 70. & ADT 53 \\
\hline 35. & Karuppu kavuni & 71. & TKM 13 \\
\hline 36. & Iravaipandi & & \\
\hline
\end{tabular}


Table.2 Analysis of variance for plant architectural and biometrical traits in rice landraces

\begin{tabular}{|c|c|c|c|c|c|c|c|c|c|c|c|}
\hline \multirow[t]{2}{*}{ Source } & \multirow[t]{2}{*}{ df } & \multicolumn{10}{|c|}{ Mean squares } \\
\hline & & DFF & PH & NPT & PL & NGPP & SFP & $\mathrm{CC}$ & $\mathrm{Na}^{+} / \mathbf{K}^{+}$ & TGW & GYP \\
\hline Genotype & 70 & 261.93 & $2125.78 * *$ & $18.13 * *$ & $17.05 * *$ & $4584.04 * *$ & $99.73 * *$ & $31.81 * *$ & $0.13 * *$ & $84.62 * *$ & $164.37 * *$ \\
\hline Replication & 2 & 51.56 & 19.29 & 0.41 & 2.40 & 24.27 & 3.68 & 5.09 & 0.01 & 0.10 & 2.22 \\
\hline Error & 140 & 1.31 & 8.13 & 0.40 & 1.47 & 4.56 & 3.27 & 1.96 & 0.00 & 0.32 & 2.03 \\
\hline
\end{tabular}

**Significant at $1 \%$ level

DFF-Days to 50\% flowering; PH-Plant height; NPT-Number of productive tillers/plant; PL-Panicle length; NGPP-Number of grains per panicle; SFP-Spikelet fertility percentage; CC-Chlorophyll content; $\mathrm{Na}^{+} / \mathrm{K}^{+}-\mathrm{Na}^{+} / \mathrm{K}^{+}$Ratio; TGW-1000 grain weight; GYP-Grain yield per plant

Table.3 Variability parameters for biometrical and physiological traits in rice landraces

\begin{tabular}{|c|c|c|c|c|c|c|c|c|}
\hline \multirow[t]{2}{*}{$\begin{array}{c}\text { S. } \\
\text { No. }\end{array}$} & \multirow[t]{2}{*}{ Characters } & \multirow[t]{2}{*}{ Mean } & \multicolumn{2}{|c|}{ Range } & \multicolumn{2}{|c|}{$\begin{array}{l}\text { Coefficient of } \\
\text { variation }\end{array}$} & \multirow[t]{2}{*}{$\begin{array}{c}h^{2} \\
(\%)\end{array}$} & \multirow[t]{2}{*}{$\begin{array}{c}\text { GAM } \\
(\%)\end{array}$} \\
\hline & & & $\underset{\mathbf{m}}{\operatorname{Minimu}}$ & $\underset{\mathbf{m}}{\operatorname{Maximu}}$ & $\begin{array}{l}\text { PCV } \\
(\%)\end{array}$ & $\begin{array}{c}\text { GCV } \\
(\%)\end{array}$ & & \\
\hline 1 & Days to $50 \%$ flowering & 87.52 & 72.00 & 108.33 & 10.73 & 10.65 & 98.52 & 21.78 \\
\hline 2 & Plant height $(\mathrm{cm})$ & 142.25 & 91.67 & 201.07 & 18.78 & 18.68 & 98.86 & 38.26 \\
\hline 3 & $\begin{array}{l}\text { Number of productive tillers per } \\
\text { plant }\end{array}$ & 10.58 & 6.13 & 16.47 & 23.75 & 22.99 & 93.68 & 45.83 \\
\hline 4 & Panicle length $(\mathrm{cm})$ & 23.36 & 18.41 & 28.66 & 11.05 & 9.76 & 77.92 & 17.74 \\
\hline 5 & Number of grains per panicle & 136.88 & 63.78 & 244.67 & 28.59 & 28.54 & 99.70 & 58.71 \\
\hline 6 & Spikelet Fertility Percentage & 90.06 & 73.66 & 98.06 & 6.61 & 6.30 & 90.78 & 12.36 \\
\hline 7 & Chlorophyll Content & 32.78 & 24.60 & 41.79 & 10.53 & 9.62 & 83.52 & 18.11 \\
\hline 8 & $\mathrm{Na}^{+} / \mathrm{K}^{+}$ratio $(\mathrm{ppm})$ & 0.35 & 0.03 & 0.94 & 59.33 & 57.66 & 94.45 & 115.44 \\
\hline 9 & 1000 grain weight $(\mathrm{g})$ & 22.98 & 13.80 & 32.58 & 23.20 & 23.07 & 98.89 & 47.26 \\
\hline 10 & Grain yield per plant $(\mathrm{g})$ & 24.09 & 9.74 & 43.36 & 31.11 & 30.54 & 96.39 & 61.77 \\
\hline
\end{tabular}

PCV - Phenotypic Coefficient of variation; GCV - Genotypic Coefficient of variation; GAM - Genetic advance as percent of mean

Heritability along with genetic advance is considered as more efficient tool for prediction of the method of improvement to be applied. High heritability coupled with high GAM were revealed by the characters viz., number of grains per panicle $(99.70 \%$, $58.71 \%), \quad 1000$ grain weight $(98.89 \%$, $47.26 \%)$, plant height $(98.86 \%, 38.26 \%)$, days to $50 \%$ flowering $(98.52 \%, 21.78 \%)$, grain yield per plant $(96.39 \%, 61.77 \%), \mathrm{Na}^{+} / \mathrm{K}^{+}$ Ratio $(94.45 \%, 115.44 \%)$, and number of productive tillers per plant $(93.68 \%, 45.83 \%)$ which implies less influence of environment hence, phenotypic selection of genotypes based on these characters could be effective. Identical findings were reported by Kushwaha et al., (2020) for plant height, thousand grain weight, days to $50 \%$ flowering, and grain yield per plant. Divya et al., (2018) obtained similar results for number of productive tillers per plant and number of grains per panicle.

The traits spikelet fertility percentage (90.78\%, 12.36\%), chlorophyll content $(83.52 \%, 18.11 \%)$ and panicle length (77.92\%, 17.74\%) exhibited high heritability and moderate GAM. The results were supported by Nithya et al., (2020) for spikelet fertility percentage and Shrivastav et al., (2020) for chlorophyll content and Jadhav et al., (2020) for panicle length, 
In this study high PCV and GCV was revealed by the traits $\mathrm{Na}^{+} / \mathrm{K}^{+}$ratio, grain yield per plant, number of grains per panicle, 1000 grain weight and number of productive tillers per plant. It indicated prevalence of variation within the population. The characters viz., number of grains per panicle, 1000 grain weight, plant height, days to $50 \%$ flowering, $\mathrm{Na}^{+} / \mathrm{K}^{+}$ratio, grain yield per plant and number of productive tillers per plant registered high heritability along with high GAM. Hence, selection of genotypes based on these characters could be effective due to additive gene action. Further, the genotype TRY 3 recorded high grain yield per plant followed by the landraces Poovan samba, Rajamannar, Katta samba and Sornakuruvai. Hence, these genotypes may be used as parents in developing improved salt tolerant lines in future breeding programme under sodic soil condition.

\section{References}

Agricultural statistics at a glance 2019. Department of Agriculture, Cooperation and Farmers Welfare, Directorate of Economics and Statistics, Ministry of Agriculture and Farmers Welfare, Government of India.

Akter, N., Khalequzzaman, M., Islam, M., Mamun, M., and Chowdhury, M. (2018). "Genetic variability and character association of quantitative traits in jhum rice genotypes." $S A A R C$ Journal of Agriculture, 16(1), 193-203.

Behera, B., Sahu, S., Kar, R. K., and Pandey, R. K. (2018). "Studies on genetic variability for some metric traits in slender grain rice genotypes." Journal of Applied and Natural Science, 10(1), 375-378.

Burton, G. W. (1952). "Quantitative inheritance in grasses." Proceedinds of VI International Grassland Congress,
1952, 277-283.

Chakraborty, K., Basak, N., Bhaduri, D., Ray, S., Vijayan, J., Chattopadhyay, K., and Sarkar, R. K. (2018). "Ionic basis of salt tolerance in plants: nutrient homeostasis and oxidative stress tolerance." Plant nutrients and abiotic stress tolerance. 325-362.

Devi, R., Venkanna, V., Hari, Y., Chandra, S., Lingaiah, N., and Rajendra, K. (2020). "Studies on genetic diversity and variability for yield and quality traits in promising germplasm lines in rice (Oryza sativa L.)." The Pharma Innovation Journal, 9(1), 391-399.

Dhakal, A., Shishir Sharma, Dk Amrit Pokhrel, A., and Poudel, A. (2020). "Variability and heritability estimate of 30 rice landraces of Lamjung and Tanahun Districts, Nepal." Indonesian Journal of Agricultural Science, 21(1), 1-10.

Divya, J., Raju, C. D., Rao, L. S., and Aparna, K. (2018). "Genetic Variability Studies in Genetically Diverse Rice Genotypes." International Journal of Current Microbiology and Applied Sciences, 7(4), 1169-1172.

Gupta, P., Verma, O., Verma, R., Gupta, R., Singh, V., Jyoti, K., and Yadav, R. (2020). "Heritability and genetic advance analysis using generation mean analysis in rice (Oryza sativa L.) under sodic soil." Journal of Pharmacognosy and Phytochemistry, 9(5), 1471-1475.

Jadhav, S., Kunkerkar, R., Thorat, B., and Keluskar, M. G. M. (2020). "Variability and genetic parameters studies in rice (Oryza sativa L.)." Journal of Pharmacognosy and Phytochemistry, 9(1), 1375-1377.

Johnson, H. W., Robinson, H., and Comstock, R. (1955). "Estimates of genetic and environmental variability in soybeans 1." Agronomy journal, 47(7), 314-318. 
Keerthana, K., Chitra, S., Subramanian, A., Nithila, S., and Elangovan, M. (2019). "Studies on genetic variability in finger millet [Eleusine coracana (L.) Gaertn] genotypes under sodic conditions." Electronic Journal of Plant Breeding, 10(2), 566-569.

Kumar, A., Kumar, S., Singh, S., Prasad, J., Jeena, A., and Upreti, M. (2020). "Genetic variability studies for yield components and quality traits in basmati rice (Oryza sativa L.)." Journal of Pharmacognosy and Phytochemistry, 9(3), 1919-1922.

Kushwaha, N., Kant, R., Kumar, R., Singh, D., Chhaya, R., Sinha, N., and Mohanty, T. A. (2020). "Character Association Studies in Lowland Rice Cultivars of Bihar." Current Journal of Applied Science and Technology, 3139.

Lush, J. L. (1940). "Intra-sire correlations or regressions of offspring on dam as a method of estimating heritability of characteristics." Journal of animal science, 1, 293-301.

Mandal, A., Obi Reddy, G., and Ravisankar,
T. (2011). "Digital database of salt affected soils in India using Geographic Information System." Journal of Soil Salinity and Water Quality, 3(1), 16-29.

Nithya, N., Beena, R., Stephen, R., Abida, P., Jayalekshmi, V., Viji, M., and Manju, R. (2020). "Genetic Variability, Heritability, Correlation Coefficient and Path Analysis of Morphophysiological and Yield Related Traits of Rice under Drought Stress." Chemical Science Review and Letters, 9(33), 48-54.

Panse, V., and Sukhatme, P. (1967). "Statistical methods for agricultural workers ICAR Publication." New Delhi, 259.

Shrivastav, S. P., Singh, V., Lal, K., Chaudhary, A. K., and Hitaishi, S. K. (2020). "Assessing Genetic Variability, Heritability and Genetic Advance in Rice (Oryza sativa L.) Under Sodic Soil." Int. J. Curr. Microbiol. App. Sci, 9(2), 3108-3115.

\section{How to cite this article:}

Manju, S., T. Thirumurugan, A. Subramanian, S. Nithila, T. Sherene Jenita Rajammal and Jeyaprakash, P. 2021. Study on genetic variability and heritability in rice landraces (Oryza sativa. L.) under sodicity. Int.J.Curr.Microbiol.App.Sci. 10(01): 709-715. doi: https://doi.org/10.20546/ijcmas.2021.1001.086 